\title{
FAKTOR-FAKTOR DETERMINAN PROFESIONALISME GURU SMK BIDANG KEAHLIAN TEKNOLOGI INFORMASI DAN KOMUNIKASI
}

\author{
Athika Dwi Wiji Utami \\ SMK Tamansiswa Jetis Yogyakarta \\ athikautami@gmail.com
}

\begin{abstract}
Abstrak: Faktor-Faktor Determinan Profesionalisme Guru SMK Bidang Keahlian Teknologi Informasi dan Komunikasi. Penelitian ini bertujuan untuk mengetahui pengaruh langsung dan tidak langsung kecerdasan emosional, kepuasan kerja dan komitmen guru, secara simultan dan parsial terhadap profesionalisme guru produktif SMK bidang keahlian TIK di kota Yogyakarta. Sampel penelitian berjumlah 66 dari 79 guru yang tersebar di 14 SMK di wilayah kota Yogyakarta. Teknik sampling menggunakan proportionate random sampling. Teknik pengumpulan data penelitian menggunakan angket tertutup. Teknik analisis menggunakan analisis jalur. Hasil penelitian menunjukkan bahwa secara parsial, kecerdasan emosional guru secara signifikan berpengaruh langsung terhadap profesionalisme guru produktif SMK bidang keahlian TIK di kota Yogyakarta, dengan kontribusi sebesar 0,701 (faktor determinan). Selanjutnya, tidak ada pengaruh langsung kepuasan kerja guru terhadap profesionalisme guru produktif SMK bidang keahlian TIK di kota Yogyakarta. Komitmen guru secara signifikan berpengaruh langsung terhadap profesionalisme guru produktif SMK bidang keahlian TIK di kota Yogyakarta, dengan kontribusi sebesar 0,224. Sementara itu, secara simultan kecerdasan emosional, kepuasan kerja dan komitmen guru secara signifikan berpengaruh terhadap profesionalisme guru produktif SMK bidang keahlian TIK di kota Yogyakarta, dengan kontribusi sebesar 57\%.
\end{abstract}

Kata Kunci: profesionalisme, kecerdasan emosional, komitmen, kepuasan kerja

\section{DETERMINANT FACTORS OF THE PROFESSIONALISM OF VOCATIONAL HIGH SCHOOL TEACHERS IN THE INFORMATION AND COMMUNICATION TECHNOLOGY}

\begin{abstract}
Determinant Factors of the Professionalism of Vocational High School Teachers in the Information and Communication Technology. This study aims to determine direct and indirect effects of teachers' emotional intelligence, job satisfaction and commitment, both simultaneously and partially, on the professionalism of Information and Communication Technology (ICT) productive teachers in the vocational high schools (VHSs) of Yogyakarta City. The research sample were 66 of 79 ICT productive teachers in 14 VHSs in Yogyakarta City. The sampling technique was proportionate random sampling. The data collecting techniques was a questionnaire. The data were analyzed using the path analysis technique. The results show that partially, teachers' emotional intelligence significantly and directly affects the ICT productive teachers' professionalism in VHSs of Yogyakarta City, with a contribution of 0,701 (determinant factor). Furthermore, teachers' job satisfaction does not directly affect the ICT productive teachers' professionalism in VHSs of Yogyakarta City. Significantly, teachers' commitment directly affects the ICT productive teachers' professionalism in VHSs of Yogyakarta City, with a contribution of 0,224. Meanwhile, simultaneously teachers' emotional intelligence, job satisfaction and commitment significantly and directly affect the ICT productive teachers' professionalism in VHSs of Yogyakarta City, with contributions by 57\%.
\end{abstract}

Keyword : Professionalism, Emotional Intelligence, Job Satisfaction, Commitment 


\section{PENDAHULUAN}

Pendidikan kejuruan yang bermutu sangat berperan terhadap pertumbuhan ekonomi dan kemajuan suatu negara. Secara konstitusi, penyelenggaraan SMK memiliki peranan strategis dalam menentukan keberhasilan pembangunan nasional. Sejalan dengan strategi pembangunan pendidikan nasional, maka penyelenggaraan SMK diarahkan salah satunga pada kebijakan perluasan akses terhadap pendidikan SMK sesuai dengan kebutuhan dan keunggulan lokal, yaitu berupa kebijakan rasio jumlah SMA : SMK menjadi 30 :70. Peningkatan jumlah SMK akan selaras dengan jumlah siswa SMK. Dengan rasio siswa nantinya sekitar $70 \%$, akan banyak dibutuhkan guru SMK yang berkualifikasi, berkompeten dan relevan dengan kebutuhan SMK.

Guru yang dianggap berkompeten dan relevan dengan kebutuhan SMK bukan hanya berkualifikasi saja tetapi juga berkomitmen untuk selalu menjadikan pendidikan sebagai pendidikan sepanjang hayat, sehingga proses perbaikan diri dan pengembangan kompetensi akan terus menerus terjadi dan menerapkannya dalam kehidupan demi masa depan peserta didik. Sementara itu, terdapat beberapa tantangan guru ke depan (Napitupulu, 2009:1), antara lain (1) perkembangan IPTEK yang cepat dan pesat akan membutuhkan guru yang berkarakteristik adaptif responsif, arif dan bijaksana; (2) arus negatif globalisasi akan membutuhkan guru yang bisa berperan aktif dan bijaksana sebagai fasilitator dan pembimbing para peserta didik; (3) krisis sosial, seperti kriminalitas dan pengangguran akan membutuhkan guru yang responsif, sehingga sekolah sebagai lembaga pendidikan formal yang mendapat kepercayaan masyarakat harus mampu menghasilkan peserta didik yang siap hidup dalam kondisi dan situasi bagaimanapun; (4) krisisidentitas sebagai bangsa dan Negara Indonesia akan membutuhkan guru yang mampu berperan sebagai penjaga nilai-nilai termasuk nilai nasionalisme kepada para peserta didiknya; dan (5) perdagangan bebas akan membutuhkan guru yang visioner, kompeten dan berdedikasi tinggi sehingga mampu membekali peserta didik dengan sejumlah kompetensi yang diperlukan sebagai bekal menghadapi persaingan global. Tantangan globalisasi di atas tersebut harus disikapi guru dengan mengedepankan profesionalisme (Kunandar, 2007: 37 - 40).

Sementara itu, berdasarkan data di lapangan menujukkan bahwa kelayakan guru dalam mengajar masih meragukan. Data Balitbang Depdiknas (sekarang Kemendiknas), hingga tahun 2007/2008 menyatakan bahwa masih banyak guru SMK yang belum berijasah S1 $(23,04 \%)$ dan sebesar 23,04\% guru SMK tidak layak mengajar pada tahun 2007/2008 (Mahdiansyah, 2010: 4). Kemudian, data Balitbang Yogyakarta 2005/2006 menyatakan untuk guru SMK hanya 56,7\% dari 147.559 guru yang layak mengajar. Sementara itu, Governing Board Members (2004) juga menunjukkan masih minimnya jumlah guru yang memenuhi kualifikasi standar pada pendidikan kejuruan di kawasan Asia Tenggara (Wagiran, 2008: 1827). 
Lalu, mengapa terjadi gap antara data di lapangan dan idealnya? Apa yang menjadi permasalahannya? Rendahnya mutu pendidikan nasional ditengarai disebabkan profesionalisme guru di Indonesia yang masih rendah dan keengganan belajar siswa. Maka, masih terbatasnya guru berkualifikasi merupakan suatu polemik tersendiri yang perlu disadari dan harus segera ditemukan solusinya. Pemerintah melakukan beberapa upaya dalam rangka meningkatkan profesionalisme para guru. Didasarkan pada amanat UU Nomor 14 Tahun 2004 mengenai Guru dan Dosen, maka pemerintah melahirkan sebuah program sertifikasi guru. Dengan guru yang profesional, maka percepatan belajar mencapai tujuannya cepat dicapai, seiring dengan hal tersebut maka kualitas hidup dan produktivitas akan meningkat.

Namun, kenyataannya menurut Ketua Ikatan Guru Indonesia (IGI), Satria Dharma, hal tersebut tidak serta merta dapat meningkatkan profesionalisme guru. Rendahnya motivasi belajar para guru ditengarai sebagai salah satu kendala yang menyebabkan peningkatan mutu dan profesionalitas ini tidak juga berhasil dicapai. Banyak guru yang tidak menekuni profesinya secara utuh, dalam artian waktu di luar jam kerjanya tidak diisi dengan pengembangan kompetensi diri sebagai guru, tetapi lebih dengan bekerja demi memenuhi kebutuhan hidup sehari-hari. Belum adanya standar profesional guru sebagaimana tuntutan di negara-negara maju. Kemungkinan rendahnya komitmen LPTK selaku pencetak guru dalam menghasilkan calon guru yang kompeten dan profesional, sehingga yang dihasilkan guru setengah jadi yang kurang patuh terhadap etika profesi; dan kurangnya motivasi guru dalam meningkatkan kualitas diri, misalnya masih rendanya motivasi guru dalam melakukan penelitian ilmiah. Di pihak siswa SMK, beban yang mereka pikul menjadi semakin berat jika dibandingkan dengan siswa SMA. Hal tersebut mengindikasikan semakin beratnya tugas dan peran guru SMK ini dalam mempersiapkan para siswanya untuk lulus UN sebelum benar-benar terjun memasuki dunia kerja yang sesungguhnya.

Apa yang kemudian terjadi? Bukan tidak mungkin bisa memunculkan penyimpangan dalam diri guru tersebut, seperti munculnya sikap pesimis dan konsep diri yang negatif pada diri guru. Hal ini tidak dapat dikatakan muncul semata-mata dikarenakan oleh skill dan kemampuan akademik guru yang rendah, tetapi dapat juga dikarenakan kesiapan psikologis guru yang rendah. Kesiapan psikologis guru ini berkaitan dengan kecerdasan emosional yang dimiliki seorang guru. Kepuasan kerja guru, yang apabila terjadi, maka akan tercemin pada perasaan guru terhadap pekerjaannya, dan kemudian diwujudkan dalam sikap positif guru terhadap pekerjaannya. Komitmen guru, yang diindikasikan guru akan memiliki kebutuhan dan harapan yang tinggi terhadap sekolah tempat mengajar dan lebih termotivasi saat harapannya terpenuhi. Maka, peneliti tertarik untuk mengkaji hubungan dan pengaruh antara kecerdasan emosional dan komitmen dan kepuasan kerja yang dimiliki guru terhadap profesionalisme guru, yang ketiga 
komponen tersebut diindikasikan determinan profesionalisme seorang guru, dengan studi kasus pada guru SMK bidang keahlian TIK di kota Yogyakarta.

\section{METODE}

Jenis dan desain penelitian ini adalah ex post facto, dimana penelitian ini bertujuan untuk meneliti suatu peristiwa yang telah terjadi dan kemudian mengamati ke belakang tentang faktor-faktor yang menyebabkan timbulnya kejadian tersebut (Iskandar, 2009:66).

Lokasi penelitian dilakukan pada Sekolah Menengah Kejuruan yang memiliki bidang keahlian Teknologi Informasi dan Komunikasi (TIK) di kota Yogyakarta. Jumlah SMK yang membuka bidang keahlian TIK di wilayah kotaYogyakartaialah14sekolah. Berdasarkan surat Keputusan Direktur Jendral Manajemen Pendidikan Dasar dan Menengah Nomor: 251/C/KEP/MN/2008, bidang keahlian TIK terdiri atas 3 kompetensi keahlian, yakni Teknik Komputer dan Informatika, Teknik Telekomunikasi dan Teknik Broadcasting. Maka, subyek penelitiannya adalah para guru produktif yang mengajar di ketiga atau salah satu dari kompetensi keahlian tersebut. Sedangkan waktu penelitian dimulai dari bulan Februari 2012 hingga Mei 2012.

Populasi dalam penelitian ini adalah para guru produktif SMK bidang keahlian TIK dengan populasi berjumlah 79 orang guru yang tersebar di 14 SMK di wilayah kota Yogyakarta.

Teknik sampling yang digunakan adalah proportionate random sampling. Berdasarkan formula empiris dari Krejcie dan Morgan (Isaac \& Michael, 1984: 192), dengan tingkat kepercayaan 95\% maka sampel jumlah guru yang menjadi responden adalah 66 orang (pembulatan ke atas).

Tabel 1. Populasi dan Sampel Guru SMK Bidang Keahlian TIK di Kota Yogyakarta

\begin{tabular}{clccc}
\hline \hline No & Nama SMK & $\begin{array}{c}\text { Status } \\
\text { SMK }\end{array}$ & $\begin{array}{c}\text { Jumlah } \\
\text { Populasi }\end{array}$ & $\begin{array}{c}\text { Jumlah } \\
\text { Sampel }\end{array}$ \\
\hline \hline 1 & SMK Negeri 3 Yogyakarta & Negeri & 8 & 7 \\
2 & SMK Negeri 2 Yogyakarta & Negeri & 15 & 12 \\
3 & SMK Negeri 7 Yogyakarta & Negeri & 5 & 4 \\
4 & SMK Negeri 5 Yogyakarta & Negeri & 10 & 8 \\
5 & SMK Muhammadiyah 2 Yogyakarta & Swasta & 4 & 3 \\
6 & SMK BOPKRI 1 Yogyakarta & Swasta & 4 & 3 \\
7 & SMK PIRI 1 Yogyakarta & Swasta & 7 & 6 \\
8 & SMK Tamansiswa Jetis & Swasta & 6 & 5 \\
9 & SMK PIRI 3 Yogyakarta & Swasta & 3 & 3 \\
10 & SMK Muhammadiyah 4 Yogyakarta & Swasta & 2 & 2 \\
11 & SMK Ibu Pawiyatan Tamansiswa & Swasta & 5 & 4 \\
12 & SMK Muhammadiyah 1 Yogyakarta & Swasta & 2 & 2 \\
13 & SMK Muhammadiyah 3 Yogyakarta & Swasta & 6 & 5 \\
14 & SMK Ma'arif 1 Yogyakarta & Swasta & 2 & 2 \\
\hline & $\quad$ Total Populasi Guru & & 79 & 66 \\
\hline
\end{tabular}


Setelah diketahui jumlah sampel responden, kemudian sampel penelitian ini dialokasikan secara proporsional untuk masing-masing sekolah dengan tujuan agar sampel nantinya dapat mewakili atau representatif terhadap populasi guru produktif SMK bidang keahlian TIK di wilayah kota Yogyakarta.

Sampel guru pada masing-masing sekolah didapat dengan membagi antara jumlah populasi guru pada sekolah tersebut dengan jumlah populasi guru kemudian hasilnya dikalikan dengan jumlah sampel responden (66). Maka, sebaran pengambilan acak sampel responden dari masing-masing sekolah dengan tingkat kepercayaan 95\% tampak pada Tabel 1. Setelah jumlah sampel diketahui dari masing-masing sekolah, maka responden guru selanjutnya ditentukan secara random pada saat dilakukan penelitian sesuai dengan jumlah sampel guru pada setiap SMK.

Dalam penelitian ini bertujuan mengungkap korelasi antara beberapa variabel bebas (independent variable) dan terikat (dependent variable), dimana variabel terikat ialah profesionalisme guru yang dinyatakan dengan simbol Y. Sedangkan, variabel bebas terdiri atas 3 variabel, antara lain kecerdasan emosional dinyatakan dengan simbol $\mathrm{X}_{1}$; kepuasan kerja dinyatakan dengan simbol $\mathrm{X}_{2}$ dan komitmen dinyatakan dengan simbol $\mathrm{X}_{3}$.

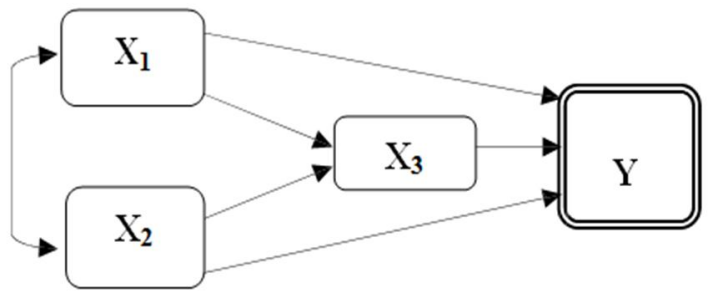

Gambar 1. Tata hubung antarvariabel bebas dan terikat

Teknik pengumpulan data penelitian menggunakan angket tertutup dan dokumentasi. Penyebaran angket kepada subyek penelitian, yakni guru produktif SMK Bidang Keahlian TIK di Kota Yogyakarta, yang bertujuan untuk memperoleh data atau informasi mengenai masalah penelitian yang menggambarkan variabel-variabel yang diteliti. Sedangkan dokumentasi bersifat studi dokumentasi berupa dokumen sekolah, resmi kelembagaan, dan referensi - referensi yang relevan dengan fokus permasalahan penelitian.

Instrumen penelitian disusun berdasarkan kajian teori dan hasil penelitian sebelumnya yang relevan. Instrumen pada variabel Kecerdasan Emosional (X1) berjumlah 16 butir pertanyaan yang dikembangkan dari kajian teori kecerdasan emosional perspektif Goleman yang terdiri atas 5 indikator yakni (a) mengenali emosi diri sendiri; (b) mengatur emosi diri sendiri; (c) memotivasikan diri sendiri, (d) mengenal emosi orang lain dan (e) membina hubungan.

Instrumen pada variabel Kepuasan Kerja (X2) berjumlah 16 butir pertanyaan, dikembangkan dari beberapa kajian teoritik relevan yang kemudian didapatkan 6 indikator, antara lain: (a) kondisi tempat kerja, (b) pekerjaan itu sendiri, (c) hubungan dengan atasan, (d) rekan kerja, (e) promosi dan (f) gaji. 
Instrumen variabel Komitmen (X3) berjumlah 7 butir pertanyaan yang dikembangkan berdasarkan kajian teori dengan perspektif Allen \& Mayer dimana terdapat 3 indikator, yakni (a) dimensi afektif, (b) dimensi berkesinambungan dan (c) dimensi normatif.

Instrumen variabel Profesionalisme guru (Y) berjumlah 90 butir pertanyaan yang dikembangkan dengan berlandaskan pada PP. No. 19 Tahun 2005, Permendiknas No. 16 Tahun 2007 dan mengadopsi angket yang bersumber dari penelitian di kota Malang (Arif Firdausi \& Barnawi, 2012 : 111), kemudian didapat 4 buah indikator, yakni (a) aktualisasi kemampuan teknis pembelajaran, aktualisasi kepribadian diri, (c) aktualisasi kemampuan komunikasi interpersonal, dan (d) aktualisasi penguasaan pengetahuan teoritik.

Sebelum dilakukan pengukuran instrumen penelitian, instrumen penelitian perlu dikonsultasikan terlebih dahulu kepada pembimbing untuk mendapatkan saran dan kritik perbaikan instrumen. Kemudian, dalam mengukur validitas instrumen penelitian ini digunakan validitas isi melalui expert judgement dengan cara berkonsultasi kepada para ahli mengenai instrumen, apakah instrumen tersebut sudah baik, diperlukan perbaikan, ataupun dirombak total. Setelah instrumen tersebut disetujui para ahli, kemudian dilanjutkan dengan validitas konstruk melalui uji coba di lapangan.

Uji coba instrumen menggunakan sampel yang berjumlah 37 responden guru yang identik dengan sampel pada penelitian ini, tetapi diambil di lokasi yang berbeda, yakni SMK "17" Seyegan, SMK Muhammadiyah 1 dan 2 Moyudan Sleman. Data hasil uji coba kemudian ditabulasikan dan dianalisis melalui rumus Product Moment dari Karl Pearson. Walaupun instrumen yang valid umumnya reliabel, tetapi pengujian reliabilitas instrumen perlu dilakukan.

Setelah didapat instrumen penelitian yang sudah valid dan reliabel berjumlah 129 butir pertanyaan, kemudian selanjutnya disebarkan kepada para responden guru produktif SMK bidang keahlian Teknologi Informasi dan komunikasi di kota Yogyakarta.

Sebelum melakukan uji hipotesis, maka sebelumnya terlebih dahulu dilakukan beberapa uji persyaratan analisis yang mencakup uji normalitas, uji lineritas, uji multikolineritas, dan uji homokedastisitas. Analisis inferensial atau pengujian hipotesis digunakan untuk menentukan apakah hipotesis nol diterima atau ditolak, dengan kata lain analisis inferensial. Hasil dari analisis ini kemudian akan digeneralisasikan untuk populasi dimana sampel diambil. Teknik analisis yang digunakan dalam penelitian ini adalah teknik analisis jalur (path analysis).

\section{HASIL DAN PEMBAHASAN}

Kerangka pikir penelitian ini diuraikan menjadi dua sub bagian struktur. Sub struktur pertama mengungkap pengaruh langsung variabel kecerdasan emosional (X1) dan kepuasan kerja (X2) terhadap komitmen guru (X3).

Sub struktur kedua mengungkap hubungan pengaruh langsun dan tidak 
langsung variabel kecerdasan emosional $\left(\mathrm{X}_{1}\right)$, kepuasan kerja $\left(\mathrm{X}_{2}\right)$, dan komitmen guru $\left(\mathrm{X}_{3}\right)$ terhadap profesionalisme guru $(\mathrm{Y})$. Maka selanjutnya, kerangka pikir tersebut dijadikan dasar perumusan hipotesis penelitian ini, yang kemudian dirumuskan menjadi dua hipotesis mayor. Hipotesis mayor pertama didasarkan pada sub struktur pertama, sementara hipotesis mayor kedua didasarkan pada sub struktur kedua. Berikut hipotesishipotesis penelitian ini diuraikan :

\section{Hipotesis Mayor Pertama}

Terdapat pengaruh langsung kecerdasan emosional dan kepuasan kerja secara simultan terhadap komitmen guru SMK bidang keahlian

Teknologi Informasi dan Komunikasi (TIK) di Kota Yogyakarta. Hipotesis mayor pertama memiliki dua hipotesis minor, yakni:

1. Terdapat pengaruh langsung kecerdasan emosional terhadap komitmen guru SMK bidang keahlian Teknologi Informasi dan Komunikasi (TIK) di Kota Yogyakarta.

2. Terdapat pengaruh langsung kepuasan kerja terhadap komitmen guru SMK bidang keahlian Teknologi Informasi dan Komunikasi (TIK) di Kota Yogyakarta

\section{Hipotesis Mayor Kedua:}

Terdapat pengaruh langsung kecerdasan emosional, kepuasan kerja dan komitmen secara simultan terhadap profesionalisme guru SMK bidang keahlian Teknologi Informasi dan Komunikasi (TIK) di Kota Yogyakarta. Hipotesis mayor kedua memiliki beberapa hipotesis minor, antara lain:
1. Terdapat pengaruh langsung kecerdasan emosional terhadap profesionalisme guru SMK bidang keahlian Teknologi Informasi dan Komunikasi (TIK) di Kota Yogyakarta.

2. Terdapat pengaruh langsung kepuasan kerja terhadap profesionalisme guru SMK bidang keahlian Teknologi Informasi dan Komunikasi (TIK) di Kota Yogyakarta.

3. Terdapat pengaruh langsung komitmen terhadap profesionalisme guru SMK bidang keahlian Teknologi Informasi dan Komunikasi (TIK) di Kota Yogyakarta.

Analisis data pada penelitian ini menggunakan metode statistik inferensial, yang bertujuan menguji hipotesis pertama hingga ketujuh melalui teknik path analysis atau analisis jalur. Teknik path analysis atau analisis jalur digunakan untuk menguji seberapa besar kontribusi yang ditunjukkan oleh koefisien jalur serta pengaruh langsung dan tidak langsung pada setiap diagram jalur dari hubungan kausal pertama yakni antara variabel $\mathrm{X} 1$ dan $\mathrm{X} 2$ terhadap X3 (hipotesis pertama hingga ketiga) serta hubungan kausal kedua yakni antara variabel X1, X2 dan X3 terhadap Y (hipotesis keempat hingga ketujuh).

Berdasarkan hasil pengolahan pada hipotesis mayor pertama dan hipotesis mayor kedua, maka rekapitulasi persamaan struktur untuk kedua yakni :

Persamaan sub struktur 1

$X_{3}=0,663 X_{1}+0,187 X_{2}+0,503 \varepsilon 1$

$R^{2} \times 3 \times 2 \times 1=0,497$. 
Persamaan sub struktur 2

$Y=0,701 X 1+0,224 \times 3+0,496 \varepsilon 2 ;$

$R^{2}$ yx3x1 $=0,754 ; R^{2}$ yx3x1 x2 =0,755

Kemudian, pemaknaan hasil perhitungan analisis jalur pada keseluruhan hipotesis diuraikan sebagai berikut :

1. Hipotesis mayor dan minor pertama menunjukkan hubungan kausal antara variabel $\mathrm{X}_{1}, \mathrm{X}_{2}$ dan $\mathrm{X}_{3}$ Hasil uji hipotesis menyatakan bahwa secara keseluruhan dan individu (hipotesis minor) dinyatakan hubungan kausal antara variabel bebas dan terikat memiliki pengaruh yang signifikan.

2. Hipotesis mayor dan minor kedua mengungkap pengaruh langsung, pengaruh tidak langsung, dan pengaruh non kausal antara variabel $\mathrm{X}_{1}, \mathrm{X}_{2}, \mathrm{X}_{3}$ dan $\mathrm{Y}$. Hasil uji hipotsis menyatakan bahwa secara keseluruhan, terdapat pengaruh yang signifikan antara $\mathrm{X}_{1}, \mathrm{X}_{2}, \mathrm{X}_{3}$ terhadap $\mathrm{Y}$. Sementara secara individu, dari ketiga hipotesis minor, hanya dua hipotesis yang menunjukkan pengaruh yang signifikan antara variabel bebas dan terikat, yakni (a) koefisien jalur $\mathrm{X}_{1}$ terhadap $\mathrm{Y}$ (kecerdasan emosional terhadap profesionalisme guru), dan (b) koefisien jalur $\mathrm{X}_{3}$ terhadap $\mathrm{Y}$ (komitmen terhadap profesionalisme guru). Sedangkan hipotesis minor yang tidak signifikan adalah koefisien jalur $\mathrm{X}_{2}$ terhadap $\mathrm{Y}$ (kepuasan kerja terhadap profesionalisme guru).
3. Beberapa pengaruh langsung dan tak langsung (melalui $\mathrm{X} 3$ ) dan pengaruh total tentang pengaruh Kecerdasan Emosional (X1), Kepuasan Kerja (X2), Komitmen Guru (X3) terhadap Profesionalisme Guru (Y) diuraikan sebagai berikut:

a. Pengaruh langsung variabel $\mathrm{X}_{1}$ terhadap X3 sebesar 0,663 (pengaruh total).

b. Pengaruh langsung variabel $\mathrm{X}_{1}$ terhadap Y sebesar 0,701 atau 0,701.

Pengaruh tidak langsung variabel $\mathrm{X}_{1}$ terhadap Y melalui $\mathrm{X}_{3}=\rho x_{3} x_{1} \times \rho_{y x}$ $3=(0,663) \times(0,224)=0,149$.

Pengaruh total $\mathrm{X}_{1}$ terhadap $\mathrm{Y}=\rho y_{1} 1+$ pengaruh tidak langsung variabel $\mathrm{X}_{1}$ terhadap Y melalui $\mathrm{X}_{3}=0,850$.

c. Pengaruh langsung variabel $\mathrm{X}_{2}$ terhadap $\mathrm{X}_{3}$ sebesar 0,187 (pengaruh total).

d. Pengaruh tidak langsung variabel $\mathrm{X}_{2}$ terhadap Y melalui $\mathrm{X}_{3}=\rho x_{3} x_{2} \times \rho y x$ $3=(0,187) \times(0,224)=0,042$.

e. Pengaruh langsung variabel $\mathrm{X}_{3}$ terhadap Y sebesar 0,224 (pengaruh total).

f. Pengaruh langsung secara simultan variabel $\mathrm{X}_{1}$ dan $\mathrm{X}_{2}$ terhadap $\mathrm{X}_{3}$ sebesar 0,497.

g. Pengaruh langsung secara simultan variabel $\mathrm{X}_{1}$ dan $\mathrm{X}_{3}$ terhadap $\mathrm{Y}$ sebesar 0,754 .

h. Pengaruh langsung secara simultan variabel $\mathrm{X}_{1}, \mathrm{X}_{2}$ dan $\mathrm{X}_{3}$ terhadap $\mathrm{Y}$ sebesar 0,755 . 
Tabel 2. Rekapitulasi dekomposisi dari koefisien jalur, pengaruh langsung dan tidak langsung, pengaruh total variabel Kecerdasan Emosional (X1), Kepuasan Kerja (X2), dan Komitmen (X3) terhadap Profesionalisme Guru (Y)

\begin{tabular}{|c|c|c|c|c|c|}
\hline \multirow[t]{2}{*}{ Pengaruh Variabel } & \multicolumn{3}{|c|}{ Pengaruh Kaussal } & \multirow[b]{2}{*}{ Sisa $_{1}$ dan $_{2}$} & \multirow{2}{*}{$\begin{array}{c}\text { Pengaruh } \\
\text { bersama }\left(\mathrm{R}^{2}\right)\end{array}$} \\
\hline & Langsung & $\begin{array}{c}\text { Tidak } \\
\text { Langsung }\end{array}$ & Total & & \\
\hline \multicolumn{6}{|c|}{ Sub Struktur 1} \\
\hline $\mathrm{X}_{1}$ terhadap $\mathrm{X}_{3}$ & 0,663 & - & 0,663 & - & \\
\hline $\mathrm{X}_{2}$ terhadap $\mathrm{X}_{3}$ & 0,187 & - & 0,187 & - & \\
\hline $\mathrm{X}_{1 \mathrm{dan}} \mathrm{X}_{2}$ terhadap $\mathrm{X}_{3}$ & - & - & 1 & 0,503 & 0,497 \\
\hline \multicolumn{6}{|c|}{ Sub Struktur 2} \\
\hline $\mathrm{X}_{1}$ terhadap $\mathrm{Y}$ & 0,701 & 0,149 & 0,850 & - & - \\
\hline $\mathrm{X}_{2}$ terhadap $\mathrm{Y}$ & - & 0,042 & 0,042 & - & - \\
\hline $\mathrm{X}_{3}$ terhadap $\mathrm{Y}$ & 0,224 & - & 0,224 & - & - \\
\hline $\mathrm{X}_{1}$ dan $\mathrm{X}_{3}$ terhadap $\mathrm{Y}$ & - & - & 1 & 0,246 & 0,754 \\
\hline $\mathrm{X}_{1}, \mathrm{X}_{2}$, dan $\mathrm{X}_{3}$ terhadap $\mathrm{Y}$ & - & - & 1 & 0,245 & 0,755 \\
\hline
\end{tabular}

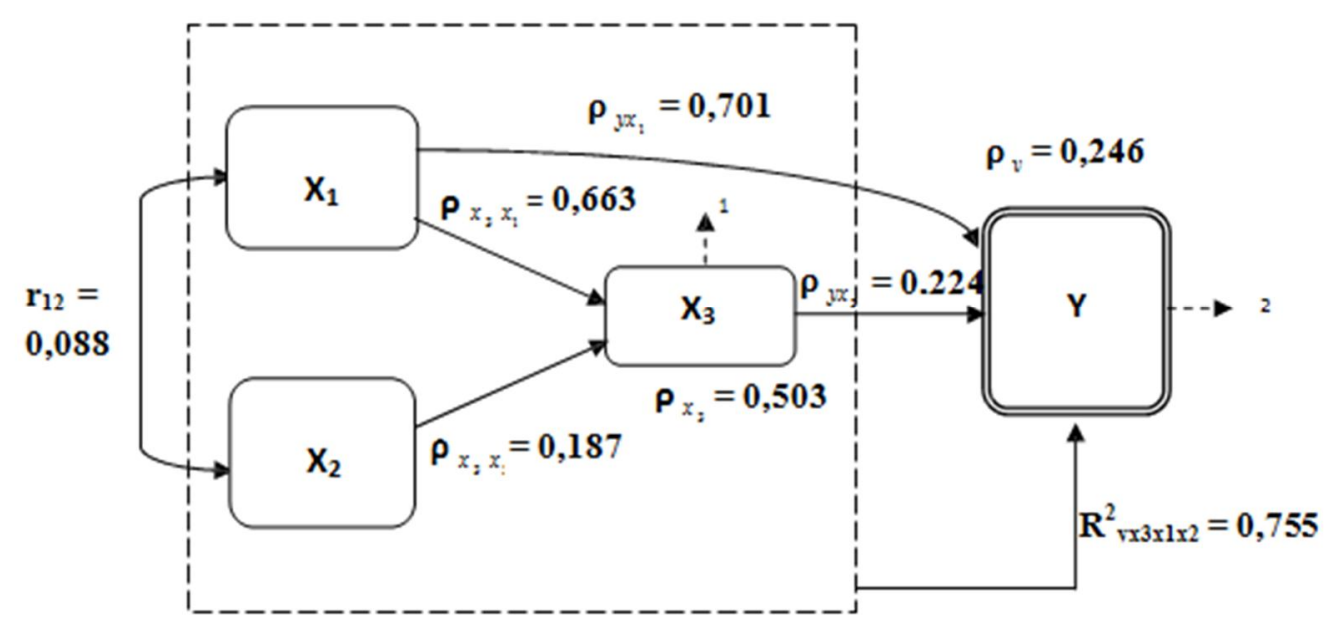

Gambar 2. Model Akhir Hubungan Kausal Empiris Struktural X1, X2, dan X3 terhadap Y

Berikut pembahasan dari hasi pengujian hipotesis dalam penelitian ini :

\section{Pengaruh Kecerdasan Emosional Guru terhadap Profesionalisme Guru}

Hasil penelitian menunjukkan bahwa terdapat pengaruh signifikan kecerdasan emosional guru terhadap profesionalisme dalam diri guru tersebut. Kontribusi yang disumbangkan sebesar 0,701 atau $49,14 \%$ yang mendiskripsikan bahwa dengan peningkatan kecerdasan emosional guru maka secara langsung dapat meningkatkan profesionalisme guru tersebut. Profesionalisme guru dibangun melalui aktualisasi dari penguasaan empat kompetensi guru, yakni aktualisasi kemampuan teknis pembelajaran, aktualisasi kepribadian diri, aktualisasi kemampuan komunikasi interpersonal dan aktualisasi penguasaan pengetahuan teoritik. Guru yang memiliki kemampuan teknis 
pembelajaran, berarti guru tersebut memiliki pemahaman terhadap peserta didik, perancangan dan pelaksanaan pembelajaran, dan pengembangan peserta didik untuk mengaktualisasikan berbagai potensi yang dimilikinya. Guru yang memiliki kepribadian diri, berarti guru tersebut dapat mencerminkan kepribadian yang mantap, stabil, dewasa, arif, berwibawa, menjadi teladan bagi peserta didik dan berakhlak mulia. Guru yang memiliki kemampuan komunikasi interpersonal, berarti guru tersebut mampu berkomunikasi dan bergaul secara efektif dengan peserta didik, sesame pendidik, tenaga kependidikan, stakeholder, orang tua / wali peserta didik, dan masyarakat sekitar. Guru yang memiliki penguasaan pengetahuan teoritik, berarti penguasaan materi pembelajaran secara luas dan mendalam, yang mencakup penguasaan materi kurikulum mata pelajaran di sekolah dan substansi keilmuan yang menaungi materinya, serta penguasaan terhadap struktur dan metodologi keilmuannya.

Dengan kecerdasan emosional yang tinggi, maka akan lebih memudahkan guru tersebut meningkatkan penguasaan keempat kompetensi itu dengan lebih baik. Guru dengan kecerdasan emosi yang tinggi, akan memiliki kemampuan komunikasi dan interpersonal sejalan dengan indikator kompetensi sosial dan kepribadian yang harus dimiliki seorang guru profesional, sehingga lebih dapat menyesuaikan diri di tengah peserta didik, orang tua serta masyarakat sekitar. Dengan kecerdasan emosional yang baik, guru lebih bersemangat dan tidak mudah menyerah dengan permasalahan yang muncul dalam lingkungan kerja sejalan dengan indikator kompetensi profesional dan pedagogik yang menuntut guru harus selalu peka dan mengembangkan diri di tengah- tengah perkembangan tuntutan stakeholder.

Lebih lanjut lagi, mereka menggunakan kemampuan tersebut untuk mengembangkan dan mengeluarkan penghambat yang mereka hadapi di karir mereka. Guru yang memiliki posisi berhubungan dengan banyak orang, lebih diterima dan disukai oleh muridnya, sebab guru tersebut memiliki kepekaan terhadap kebutuhan orang lain dan rasa humor secara proporsional. Besarnya kontribusi kecerdasan emosional terhadap profesionalisme guru, menunjukkan bahwa peningkatan profesionalisme seorang guru dapat diupayakan dengan peningkatan kecerdasan emosional.

\section{Pengaruh Kepuasan Kerja Guru terhadap Profesionalisme Guru}

Hasil penelitian menunjukkan bahwa secara langsung, tidak terdapat pengaruh signifikan antara kepuasan kerja guru terhadap profesionalisme dalam diri guru tersebut. Profesionalisme guru tampak pada tingkah laku guru tersebut saat menjalankan profesi keguruannya. Bagaimana seorang guru dapat berperan sebagai guru yang ideal sementara sebagai manusia biasa, guru tersebut memiliki berbagai permasalahan dalam hidupnya, namun seorang guru harus tetap bisa menunjukkan perilaku profesionalismenya.

Tidak adanya pengaruh langsung yang signifikan antara kepuasan kerja guru dengan profesionalisme guru kemudian dapat 
dijelaskan dengan teori dua faktor Herzberg. Indikator kepuasan kerja pada penelitian ini antara lain situasi kerja, pekerjaan itu sendiri, pimpinan, promosi, rekan kerja dan gaji. Indikator promosi digolongkan pada faktor motivator atau faktor intrinsik yang mempengaruhi kepuasan kerja. Sementara indikator lainnya digolongkan pada faktor hygiene yakni faktor ekstrinsik yang mempengaruhi ketidakpuasan kerja seseorang. Herzberg berpendapat bahwa ketika faktorfaktor hygiene telah terpenuhi, orang tersebut tidak akan merasa tidak puas, namun bukan berarti juga mereka merasa puas (netral). Lebih lanjut lagi, Herzberg menyatakan bahwa jika ingin memotivasi individu dalam pekerjaannya, maka penekanan yang dilakukan seharusnya lebih terfokus pada faktor-faktor yang berhubungan dengan pekerjaan itu sendiri atau dengan hasil-hasil yang berasal darinya, seperti pengakuan, tanggung jawab, promosi dan pencapaian (faktor motivator). Apabila faktor hygiene diperbaiki misalnya dengan memperbaiki hubungan dengan pimpinan, rekan kerja, kenaikan gaji dan status, dan perbaikan kondisi fisik kerja mungkin akan menghadirkan kenyamanan, tetapi bukan memotivasi. Oleh sebab itu, untuk meningkatkan sikap kerja guru yang lebih positif, maka lebih difokuskan pada faktor motivator seperti pengakuan, promosi dan tanggungjawab. Sebab, seorang guru yang merasa puas hanya dikarenakan peningkatan dalam faktor hygiene (gaji, hubungan rekan kerja, kepsek, situasi kerja dan status),tidak serta merta akan memberikan sikap kerja yang lebih positif.

\section{Pengaruh Komitmen Guru terhadap Profesionalisme Guru}

Hasil penelitian menunjukkan bahwa secara langsung, terdapat pengaruh signifikan komitmen guru terhadap profesionalisme dalam diri guru tersebut. Kontribusi yang disumbangkan sebesar 0,224 atau 5,02\%yang mendiskripsikan bahwa dengan peningkatan komitmen guru maka secara langsung dapat meningkatkan profesionalisme guru tersebut.

Guru dengan kualitas profesionalisme tinggi memiliki arti bahwa guru tersebut selalu berusaha menampilkan perilaku yang mendekati standar ideal, merasa bangga terhadap pekerjaannya dan selalu memperbaiki kualitas dirinya. Guru dengan komitmen tinggi maka secara langsung dan kontinyu akan meningkatkan profesionalisme dalam dirinya. Guru dengan komitmen tinggi cenderung melibatkan diri dengan frekuensi lebih tinggi dan memiliki rasa tanggung jawab yang lebih tinggi juga. Guru akan melibatkan diri pada setiap usaha perkembangan pendidikan siswanya melalui pengembangan kompetensi diri dan bertanggung jawab penuh terhadap hasil belajar para siswanya.

\section{Pengaruh Kecerdasan Emosional, Kepuasan Kerja dan Komitmen terhadap Profesionalisme Guru (Determinan Profesionalisme Guru)}

Hasil penelitian menunjukkan bahwa tingkat profesionalisme guru produktif SMK Bidang Keahlian Teknologi Informasi dan Komunikasi di kota Yogyakarta termasuk dalam kategori baik dengan pencapaian skor sebesar $72,73 \%$, dimana skor yang rendah dalam dimensi aktualisasi penguasaan pengetahuan 
teoritik,yang dapat diartikan penguasaan mendalam materi pembelajaran yang mencakup penguasaan materi kurikulum mata pelajaran di sekolah dan substansi keilmuan yang menaungi materi serta penguasaan terhadap struktur dan metodologi keilmuan masih rendah. Sementara itu, skor yang tertinggi dalam dimensi aktualisasi kepribadian diri, yang dapat diartikan kemampuan guru dalam mencerminkan kepribadian yang mantap, stabil, dewasa, arif, berwibawa, dan menjadi teladan bagi muridnya tergolong sangat baik. Sementara itu, uji hipotesis menyatakan bahwa terdapat pengaruh signifikan dan simultan antara kecerdasan emosional, kepuasan kerja dan komitmen guru terhadap profesionalisme dalam diri guru tersebut. Kontribusi yang disumbangkan sebesar $57 \%$, yang mendiskripsikanbahwa dengan peningkatan kecerdasan emosional, kepuasan kerja dan komitmen guru maka secara langsung dan simultan dapat meningkatkan profesionalisme guru tersebut.

Guru yang profesional berperan sebagai komunikator dan fasilitator. Guru profesional memilki tanggung jawab terhadap apa yang dia ajarkan dalam arti tujuan tidak hanya terhenti di dalam kelas saja saat proses belajar mengajar formal, melainkan berkomitmen dalam pencapaian tujuan peningkatan kompetensi siswa seutuhnya. Sebagai fasilitator, guru yang profesional harus lebih aktif dan peka terhadap permasalahan belajar siswa, sehingga dapat menfasilitasi pemecahan permasalahan yang dialami siswanya. Guru profesional wajib selalu mengembangkan pengetahuan dan keahliannya. Guru tersebut juga harus peka terhadap perubahan-perubahan yang terjadi di dunia pendidikan dan dituntut cepat menyesuaikan diri melalui kegiatan-kegiatan pengembangan diri, seperti workshop dan seminar. Guru profesional akan komitmen secara pribadi dan bersama- sama berusaha mengembangkan diri dan profesinya. Guru profesional akan komitmen terhadap pelayanan kepada siswa dan stakeholder. Guru harus mengutamakan pelayanan sehingga akan selalu dihadapkan dengan tantangan saat memberikan pelayanan yang optimal. Guru profesional memberikan layanan kepada siswa, dimana umur siswa SMK yang masih dalam masa puber, sehingga guru harus memberikan perhatian penuh dan ekstra hati-hati. Kecerdasan emosional yang baik, akan membantu guru tersebut menghadapi semua tantangan dan tanggung jawab yang diberikan.Kecerdasan emosional akan membantu guru dalam memecahkan permasalahan sosial dan mengontrol emosi seseorang. Lebih lanjut lagi, guru tersebut akan memiliki kemampuan melihat sesuatu dari sudut pandang orang lain sehingga guru bisa lebih bijak dalam bertindak dan pengambilan keputusan. Kecerdasan emosional juga menempatkan guru menjadi pribadi yang dapat menghadapi situasi yang berbeda. Sementara itu, guru yang merasa puas akan cenderung memberikan sikap positif yang terlihat dalam pekerjaannya. Dengan komitmen yang baik, guru akan secara tidak langsung akan terbentuk suatu rasa tanggung jawab yang besar dalam dirinya untuk selalu menjaga setiap amanah 
yang diberikan padanya serta dengan sadar lebih mudah terdorong dan terjaga motivasi dalam dirinya untuk selalu menjaga dan meningkatkan tingkat profesionalisme dalam dirinya. Berdasarkan hasil penelitian, dengan peningkatan salah satu aspek dari kepuasan kerja, antara lain kondisi pekerjaan, status pekerjaan,gaji, hubungan dengan kepala sekolah, rekan kerja dan promosi, maka guru dapat menjadi lebih puas terhadap pekerjaannya. Namun, dalam upaya peningkatan profesionalisme guru, maka peningkatan kepuasan kerja melalui aspek promosi lebih dianjurkan tentunya tanpa mengenyampingkan faktor-faktor lainnya. Pemberian kesempatan dan tanggung jawab kepada seorang guru untuk mengembangkan kompetensi diri, akan meningkatkan kreatifitas dan motivasi guru tersebut. Namun, apabila sebuah pekerjaan atau tugas tidak memberi kepuasan kepadanya, maka cenderung terjadi pengabaian terhadap pekerjaan tersebut dengan mengalihkan perhatian dan energinya ke hal-hal lain di luar kepentingan sekolah. Perbaikan tingkat kecerdasan emosional dalam diri guru dapat dilakukan melalui penciptaan budaya dan iklim kerja yang nyaman, kondusif dan saling mendukung antara rekan kerja dan kepala sekolah. Dengan pengupayaan peningkatan kedua variabel tersebut secara bersama-sama, maka secara langsung akan menumbuhkan rasa komitmen dalam diri guru sebagai feedback positif dari apa yang telah didapatkannya, yang selanjutnya akan berdampak pada peningkatan rasa profesionalisme dalam diri guru tersebut.

\section{KESIMPULAN}

Berdasarkan hasil penelitian dan pembahasan, maka dapat ditarik simpulan sebagai berikut :

1. Kecerdasan emosional guru secara signifikan berpengaruh langsung terhadap komitmen guru produktif SMK Bidang Keahlian Teknologi Informasi dan Komunikasi (TIK) di kota Yogyakarta, dengan kontribusi sebesar 0,663.

2. Kepuasan kerja guru secara signifikan berpengaruh langsung terhadap komitmen guru produktif SMK Bidang Keahlian Teknologi Informasi dan Komunikasi (TIK) di kota Yogyakarta, dengan kontribusi sebesar 0,187 .

3. Kecerdasan emosional dan kepuasan kerja guru secara signifikan dan simultan berpengaruh langsung terhadap komitmen guru produktif SMK Bidang Keahlian Teknologi Informasi dan Komunikasi (TIK) di kota Yogyakarta, dengan kontribusi sebesar $24,7 \%$.

4. Kecerdasan emosional guru secara signifikan berpengaruh langsung terhadap profesionalisme guru produktif SMK Bidang Keahlian Teknologi Informasi dan Komunikasi (TIK) di kota Yogyakarta, dengan kontribusi sebesar 0,701.

5. Kepuasan kerja guru tidak berpengaruh langsung terhadap profesionalisme guru produktif SMK Bidang Keahlian Teknologi Informasi dan Komunikasi (TIK) di kota Yogyakarta.

6. Komitmen guru secara signifikan berpengaruh langsung terhadap 
profesionalisme guru produktif SMK Bidang

Keahlian Teknologi Informasi dan Komunikasi (TIK) di kota Yogyakarta, dengan kontribusi sebesar 0,701.

7. Kecerdasan emosional, kepuasan kerja dan komitmen guru secara signifikan dan simultan berpengaruh terhadap profesionalisme guru produktif SMK Bidang Keahlian Teknologi Informasi dan Komunikasi (TIK) di kota Yogyakarta, dengan kontribusi sebesar 57\%.

8. Kecerdasan emosional berpengaruh tidak langsung melalui komitmen terhadap profesionalisme guru produktif SMK Bidang Keahlian Teknologi Informasi dan Komunikasi (TIK) di kota Yogyakarta, dengan kontribusi sebesar 0,149 .

9. Kepuasan kerja berpengaruh tidak langsung melalui komitmen terhadap profesionalisme guru produktif SMK Bidang Keahlian Teknologi Informasi dan Komunikasi (TIK) di kota Yogyakarta, dengan kontribusi sebesar 0,042.

\section{DAFTAR PUSTAKA}

Depdiknas. 2008. Ikhtisar Data Pendidikan Nasional Tahun 2007/2008.
Isaac \& Michael. 1984. Handbook in Research and Evaluation. California : EdiTS Publishers.

Iskandar. 2009. Metodologi Penelitian Pendidikan dan Sosial (Kuantitatif dan

Kualitatif). Jakarta: Gaung Persada.

Kunandar. 2010. Guru Profesional. Jakarta : Rajagrafindo Persada.

Mahdiansyah. 2010. Perilaku professional guru kejuruan hasil penelitian di SMK negeri DKI Jakarta [Versi Elektronik], Jurnal Penelitian Kebijakan Pendidikan (Litjak), 9, 1 - 23.

Meyer, J P \& Allen, N J. 1991. A threecomponent conceptualization of organizational commitment : some methodological considerations [Versi elektronik], Human Resource Management Review, 1, 61-98.

Mulyasa. 2008. Standar Kompetensi dan Sertifikasi Guru. Bandung : Remaja Rosdakarya.

Napitupulu, E. L. 4 Oktober 2009. Investasi pada guru, ciptakan masa depan pendidikan yang baik. Kompas. Diambil tanggal 8 Desember 2011, dari http://www.kompas.com/lipsus112009/kp kread/2009/10/04/18200355/Investasi.pad a.Guru..Ciptakan.Masa.Depan.Pendidikan yang.Baik.

Wagiran. 2008. Butir-butir pemikiran pengembangan pendidikan vokasi secara holistik [Versi Elektronik]. Disajikan dalam Seminar Internasional Revitalisasi Pendidikan Kejuruan dalam Pengembangan SDM Nasional APTEKINDO, $1825 \quad-\quad 1834$. 